\title{
EXPERIMENTAL STUDY ON BOND STRENGTH OF ADHESIVE POST-INSTALLED REBAR SYSTEMS DURING FIRE
}

\author{
接着系あと施工アンカーの火災時の付着強度に関する実験的研究 \\ Le Tien Thuan ${ }^{* 1}$, Seira OWA ${ }^{* 2}$, Changsuk SONG ${ }^{* 3}$ \\ and Kenichi IKEDA*4 \\ レーテエンスアン, 大和征良, 宋 昌錫, 池田憲一
}

\begin{abstract}
The experiments of post-installed adhesive rebar systems were taken in focusing on bond failure during the fire condition. The bond strengths have different performances depending on kinds of injection. Epoxy type decreased to about 1/10 in about $280^{\circ} \mathrm{C}$, Urethane type decreased about $1 / 5$ in about $200^{\circ} \mathrm{C}$, and Inorganic type reduced about $1 / 3$ in about $270^{\circ} \mathrm{C}$. The test results are close to the prediction process for Epoxy while the two other resins fluctuated widely. The heating then loading test can be used as a method for predicting the bond strength of loading then heating test in the range of temperature from $50^{\circ} \mathrm{C}$ to $100^{\circ} \mathrm{C}$.
\end{abstract}

Keywords: Adhesive Injection Post-installed Anchors, Epoxy Resin, Urethane Resin, In-organic Resin Bond Strength, During Fire 接着剂注入方式あと施工アンカー, エポキシ樹脂，ウレタン樹脂，無機系樹脂，付着強度，火災時

\section{Introduction}

Nowadays, the functional safety of constructions constitutes a prime element of the civil system serving people. The one which accounted for it is anchoring system. In Japan, the seismic retrofitting is very important, and post-installed anchoring systems have played a vital role in it. They are generally used as fasteners in seismic retrofitting of older buildings and therefore knowledge of their load-bearing capacity especially in extraordinary situations such as fire condition is crucial. In post-installed anchoring system, anchors are set into already hardened concrete by drilling a hole and inserting the anchor and connecting with concrete by a synthetic resin. This type is adhesive post-installed anchoring system and is the primary focus of this study.

In the past, a few kinds of research (1) - (3) in the US and Europe have been conducted for this post-installed anchoring system during the fire condition. In Japan, the residual capacity of adhesive anchors which used Japanese reinforcing bar together with three kinds of adhesive in the researches has also been investigated at ordinary temperature but insufficiency for the high-temperature condition. To be more specific, the long-term fire condition researches have been defined previously in (4) - (6) while in the short-term condition researches on this topic are lacking in data and necessary for reliable fire design to comprehend the bond strength performance of adhesive post-installed rebar systems under fire condition. The experiment has been done with the equipment of Tokyo University of Science (TUS) laboratory. In this study, Japan steel rebar was used together with three kinds of adhesive resin in two patterns of heating and loading parameter: heating then loading and loading then heating. There are three types of possible failure modes: Steel failure, Concrete failure, and Bond failure. The bond failure is the primary failure mode to investigate. It ensures the specifications data and suitable for the testing system.

\section{Experiments}

\section{1 Purpose of experiments}

The experiments are tensile pull-out tests on adhesive post-installed anchor subjected to high temperatures to investigate their performance during the event of a fire in a building. For the pattern I test, a tensile load is increased at a constant high temperature, while for the pattern II test, the temperature is raised to a steady tensile load. The experiments

\footnotetext{
*1 Grad. Student, Graduate School of Global Fire Science and Technology, Tokyo University of Science, M.Eng.

*2 Technical Engineer, Hilti Japan Ltd., Dr.Eng.

* 3 Technical Engineer, Hilti Japan Ltd., Ph.D. in Biomaterial Science

* 4 Prof., Graduate School of Global Fire Science and Technology, Tokyo University of Science, Dr.Eng.
}

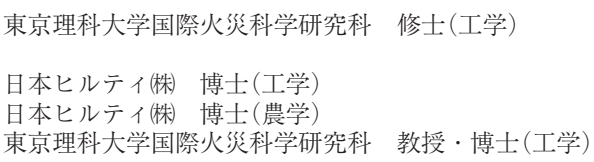

東京理科大学国際火災科学研究科 修士(工学)

日本ヒルティ侏) 博士(工学)

日本ヒルティ侏) 博士(農学)

東京理科大学国際火災科学研究科 教授・博士 (工学) 
correspond to a situation where the fastening is continuously under a tensile load, and then a fire occurs. The main point of the tests is the investigation of how the adhesive post-installed anchor systems react when a high load is applied in two patterns of heating and loading parameter. From there, the outcome data is used for comparison of two patterns to figure out if there is a connection. This is important to understand the behavior of the material overall and corresponds to the situation of a fastening that is under pure tensile load in normal conditions.

According to the conclusion, the understanding of construction system under the fire could be withdrawn. The analysis of bond strength can help to engineer in design methods and applications.

Overall 46 specimens are investigated in temperatures from $40^{\circ} \mathrm{C}$ to $200^{\circ} \mathrm{C}$. The tests were carried out in the testing facilities of TUS.

\section{2 Experiment setup}

In these tests, the specimens were filled with concrete in a steel cylinder. The rebar, D16 (SD685) and the adhesive post-installed anchors to be tested are installed. Two thermocouples are installed to measure the temperature inside of the specimens. Table 1 shows the properties of the concrete cylinder which have been used for the specimens.

Table 1 Concrete properties of specimens

\begin{tabular}{|c|c|c|c|c|}
\hline \multirow{2}{*}{$\begin{array}{c}\text { Concrete } \\
\text { cylinder }\end{array}$} & Height & Depth & $\begin{array}{c}\text { Hole } \\
\text { diameter }\end{array}$ & $\begin{array}{c}\text { Compressive } \\
\text { strength }\end{array}$ \\
\cline { 2 - 5 } & $300 \mathrm{~mm}$ & $150 \mathrm{~mm}$ & $20 \mathrm{~mm}$ & $28 \mathrm{~N} / \mathrm{mm}^{2}$ \\
\hline
\end{tabular}

The rebar used in the tests is Japanese rebar which is suitable for constructions in Japan. The highest strength of rebar steel has been chosen to eliminate steel failure as the decisive failure mechanism. The properties of steel which have been used for the specimens are given in Table 2 below.

Table 2 Steel properties of anchor specimens

\begin{tabular}{|c|c|c|}
\hline $\begin{array}{c}\text { Steel } \\
\text { Designation }\end{array}$ & Yield strength & Tensile strength \\
\hline SD 685 & $685 \mathrm{~N} / \mathrm{mm}^{2}$ & $860 \mathrm{~N} / \mathrm{mm}^{2}$ \\
\hline Diameter & Embedment dept $\mathrm{l}_{\mathrm{e}}$ & Total length \\
\hline D16 & $160 \mathrm{~mm} / 10 \mathrm{~d}_{\mathrm{a}}$ & $800 \mathrm{~mm}$ \\
\hline
\end{tabular}

There are 3 kinds of resin which are used for connecting the rebar and concrete: epoxy resin (E), urethane resin (U) and inorganic (O) (cement). Each of them has different chemical properties. Table 3 shows the properties of each adhesive resins.
Table 3 The properties of adhesive resins

\begin{tabular}{|c|c|c|}
\hline \multicolumn{3}{|c|}{ Epoxy resin (E) } \\
\hline \multirow{2}{*}{$\begin{array}{c}\text { Main Contained } \\
\text { Component }\end{array}$} & Resin & Adhesion \\
\hline & $\begin{array}{c}\text { Bisphenol A + } \\
\text { Bisphenol B }\end{array}$ & $\begin{array}{c}\text { Meta-xylene- }^{-} \\
\text {diamine + Quartz }\end{array}$ \\
\hline$\sigma_{\mathrm{c}}(\mathrm{MPa})$ & 109.0 & 108.0 \\
\hline$\sigma_{\mathrm{t}}(\mathrm{MPa})$ & 75.7 & 45.1 \\
\hline$\sigma_{\mathrm{M}}(\mathrm{MPa})$ & 118.0 & 66.7 \\
\hline$\sigma_{\mathrm{st}}(\mathrm{MPa})$ & 10.3 & 7.5 \\
\hline$\tau_{a, n}(\mathrm{MPa})$ & \multicolumn{2}{|c|}{25} \\
\hline \multicolumn{3}{|c|}{ Urethane resin (U) } \\
\hline \multirow{2}{*}{$\begin{array}{c}\text { Main Contained } \\
\text { Component }\end{array}$} & Resin & Adhesion \\
\hline & $\begin{array}{c}\text { Urethane + } \\
\text { Acrylate }\end{array}$ & Benzoylperoxide \\
\hline$\sigma_{\mathrm{c}}(\mathrm{MPa})$ & 139.0 & 85.6 \\
\hline$\sigma_{t}(\mathrm{MPa})$ & 25.8 & 8.5 \\
\hline$\sigma_{\mathrm{M}}(\mathrm{MPa})$ & 79.9 & 20.8 \\
\hline$\sigma_{\text {st }}(\mathrm{MPa})$ & - & 5.2 \\
\hline$\tau_{a, n}(\mathrm{MPa})$ & \multicolumn{2}{|c|}{19} \\
\hline \multicolumn{3}{|c|}{ In-organic resin $(0)$} \\
\hline \multirow{2}{*}{$\begin{array}{c}\text { Main Contained } \\
\text { Component }\end{array}$} & \multicolumn{2}{|c|}{ Materials } \\
\hline & \multicolumn{2}{|c|}{ Cement based mortar + Accelerator } \\
\hline$\sigma_{\mathrm{c}}(\mathrm{MPa})$ & \multicolumn{2}{|c|}{53.7} \\
\hline$\sigma_{\mathrm{t}}(\mathrm{MPa})$ & \multicolumn{2}{|c|}{-} \\
\hline$\sigma_{M}(\mathrm{MPa})$ & \multicolumn{2}{|c|}{-} \\
\hline$\sigma_{\mathrm{st}}(\mathrm{MPa})$ & \multicolumn{2}{|c|}{-} \\
\hline$\tau_{a, n}(\mathrm{MPa})$ & \multicolumn{2}{|c|}{20} \\
\hline
\end{tabular}

Note) $\sigma_{\mathrm{c}}$ : Compressive strength, $\sigma_{\mathrm{t}}$ : Tensile strength, $\sigma_{\mathrm{M}}$ : Bending strength, $\sigma_{\mathrm{st}}$ : Tensile shear bond strength, $\tau_{\mathrm{a}, \mathrm{n}}$ : Bond strength of adhesive resins

\section{2. 1 Specimen}

The specimen has the same type as in the CSTB/EOTA experiments [CSTB 2011] (7), so it is easy to compare. The picture and dimension of the specimen are given in Figure 1.
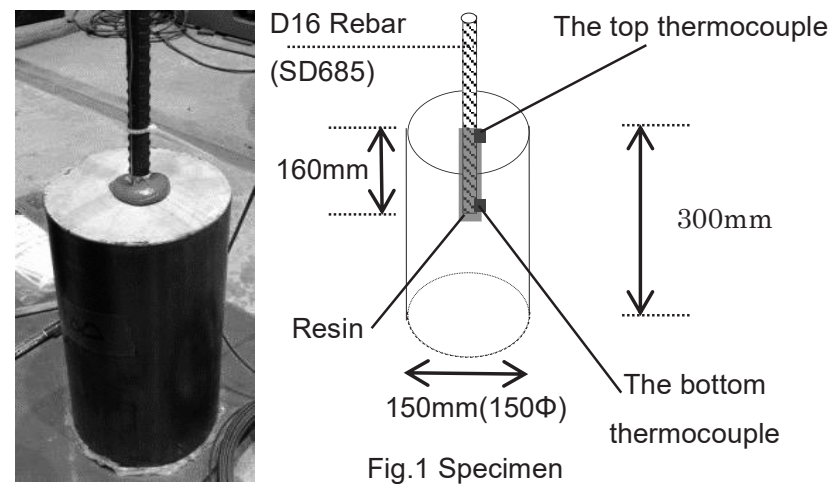

Fig.1 Specimen 
The block of concrete (diameter $150 \mathrm{~mm}$, height $300 \mathrm{~mm}$ ) is manufactured in the factory using ordinary Portland cement concrete (design standard strength $\mathrm{Fc}=15 \mathrm{~N} / \mathrm{mm}^{2}$ ). The rebar (D16, diameter $\left(d_{a}\right) 16 \mathrm{~mm}$ ) is inserted through a drilled hole (diameter $20 \mathrm{~mm}$ and effective embedment depth $\left(10 \mathrm{~d}_{\mathrm{a}}\right) 160 \mathrm{~mm}$ ) and fastened with three kinds of adhesions, epoxy resin, urethane resin and inorganic. The high strength rebar (SD685, yield strength $685 \mathrm{~N} / \mathrm{mm}^{2}$ ) is used due to focusing on bond failure. Besides, two thermocouples are installed to measure the temperature in the bonded part. One of the thermocouples is inserted down to the bottom of the hole, and the other is inserted in the position of about $30 \mathrm{~mm}$ from the top surface in the concrete hole.

\section{2. 2 Setup}

The central test equipment of Universal testing machine (Tokyo KOKI) was used (capability $1,000 \mathrm{kN}$ ). The electrical oven body consists of two halves that can be opened and closed. It is placed around the test specimen in the hydraulic jack. The rebar of the specimen is fastened in the jack which puts on the tension load. The displacement of anchors is measured in average deformations measured by displacement meters. The meters are put on the top of a displacement jig steel which is fixed to the rebar of the specimen. When the deformation starting occurred, the displacement jig moves down together with the specimen. Thus, the deformation can be measured. At the indicative displacement of $30 \mathrm{~mm}$ it is considered bond failure. Failure modes of post-installed adhesive anchors are the following three modes mainly, steel failure (S), concrete cone failure (C) and bond failure (B). This experiments focusing on the performance of bond failure (B) therefore the high strength rebars are used due to preventing steel failure mode, and the steel plate on the surface of the concrete in specimens are put in order to prevent concrete cone failure mode. Photo 1 and Photo 2 show the test equipment.

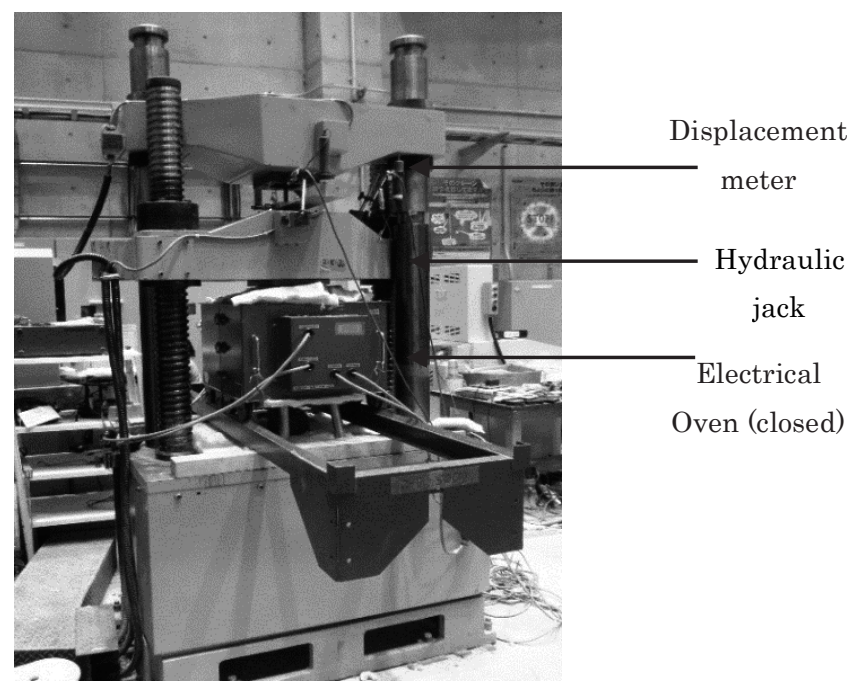

Photo 1 Test equipment with specimen fastened in jack

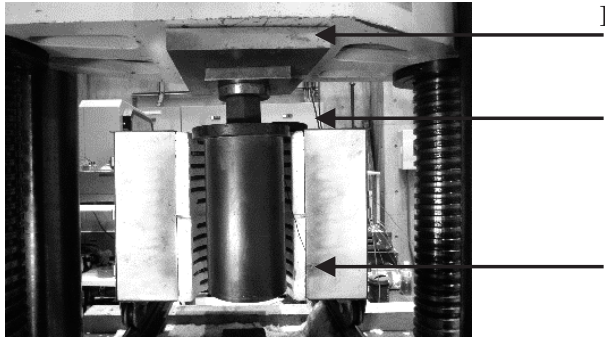

Bearing Steel Plate

(Transfer the load)

Steel Plate 1

(Prevention of

Concrete Failure)

Electrical Oven

(opened)

Photo 2 Setup of the test specimen

Photo 3 shows the displacement meters and jig steel were set up to the universal testing machine. The measuring figure of displacement has been shown in Figure 2.
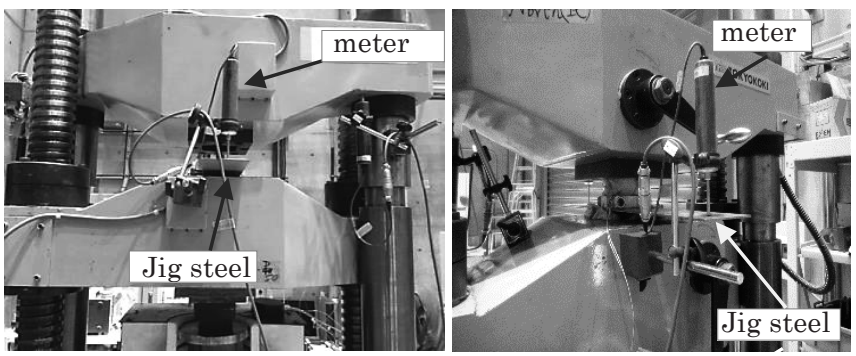

Photo 3 Displacement meter and jig steel
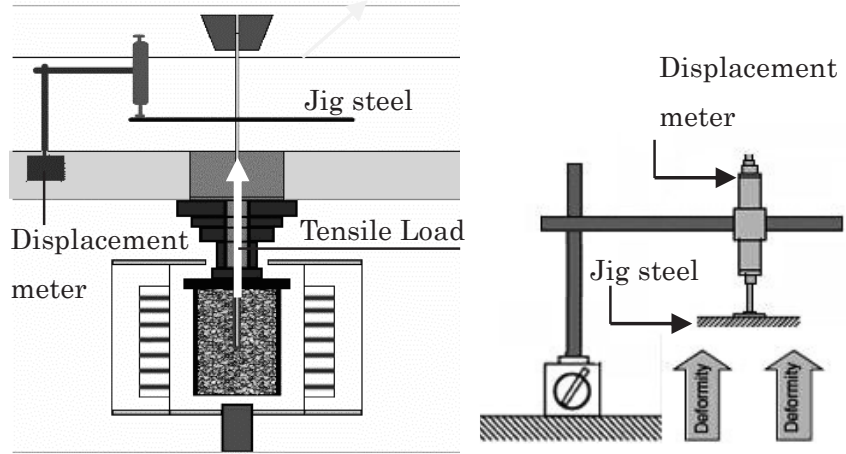

Fig.2 Measuring of displacement

\section{2. 3 Heating and Loading Condition}

The parameters conditions were "during the fire," the adhesive post-installed anchor has been heated-up for hours until it reaches the specific temperature and together with tensile load has been applied with different forces. The heating and loading condition was considered in two patterns:

* Pattern I: Heating then Loading until the bond failure occurred ( The tensile load is increased at a constant high temperature)

* Pattern II: Loading then Heating until the bond failure occurred. (The temperature is raised to a steady tensile load)

The heating and loading conditions of the experiment can be seen in Figure 3. 


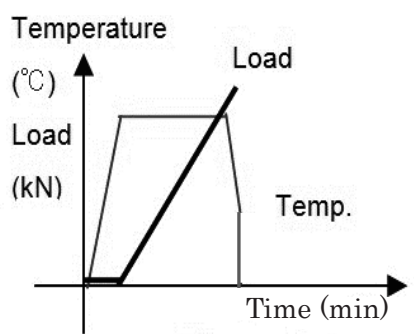

Pattern I

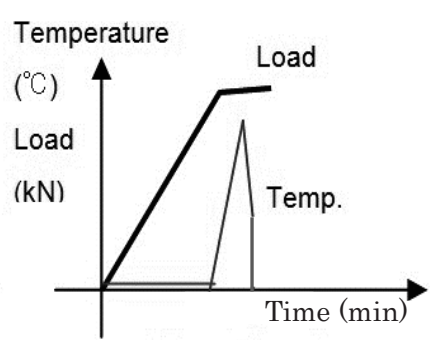

Pattern II

Fig. 3 Heating and Loading conditions of the experiment

\section{2. 3. 1 Pattern I}

In the pattern I test, the tensile load applied to specimens for each temperature is determined and after that, the results are used as the source to do the pattern II test. The results of the pattern I have been determined by methods of prediction and experiment tests.

Determined by the prediction: At normal temperature $\left(20^{\circ} \mathrm{C}\right)$, according to Japan Building Disaster Prevention Association (JBDPA), the guideline for seismic retrofitting (8) and design recommendations for composite constructions (9). The equations that defined the design of tensile strength for a single anchor are below.

Tensile Strength $\left(T_{a}\right)$

Steel failure $\left(T_{a 1}\right)$

Concrete failure $\left(T_{a 2}\right)$

Bond failure $\left(T_{a 3}\right)$

$$
\begin{aligned}
& \mathrm{T}_{\mathrm{a}}=\min \left[\mathrm{T}_{\mathrm{a} 1}, \mathrm{~T}_{\mathrm{a} 2}, \mathrm{~T}_{\mathrm{a} 3}\right] \\
& \mathrm{T}_{\mathrm{a} 1}=\sigma_{\mathrm{y}} \cdot \mathrm{a}_{0} \\
& \mathrm{~T}_{\mathrm{a} 2}=0.23 \cdot \sqrt{\sigma_{\mathrm{B}}} \cdot \mathbf{A}_{\mathrm{c}} \\
& \mathrm{A}_{\mathrm{c}}=\pi \cdot \mathbf{l}_{\mathrm{e}} \cdot\left(\mathrm{d}_{\mathrm{a}}+\mathbf{l}_{\mathrm{e}}\right) \\
& \mathrm{T}_{\mathrm{a} 3}=\tau_{\mathrm{a}} \cdot \pi \cdot \mathbf{d}_{\mathrm{a}} \cdot \mathbf{l}_{\mathrm{e}} \\
& \tau_{\mathrm{a}}=10 \cdot \sqrt{\sigma_{\mathrm{B}} / 21}
\end{aligned}
$$

Note) $\sigma_{\mathbf{y}}$ : Yield tensile strength of rebar $\left(\mathrm{N} / \mathrm{mm}^{2}\right), \mathbf{a}_{0}$ : Nominal area of rebar $\left(\mathrm{mm}^{2}\right), \sigma_{\mathrm{B}}:$ Concrete compressive strength $\left(\mathrm{N} / \mathrm{mm}^{2}\right), \mathbf{A}_{\mathbf{c}}:$ Effective area projected of a single anchor in concrete failure $\left(\mathrm{mm}^{2}\right), \mathrm{l}_{\mathrm{e}}$ : Effective embedment depth $(\mathrm{mm}), \mathbf{d}_{\mathbf{a}}:$ Diameter of rebar $(\mathrm{mm}), \tau_{\mathbf{a}}:$ Bond strength $\left(\mathrm{N} / \mathrm{mm}^{2}\right)$.

However, in the prediction of the bond failure according to JBDPA, the actual bond strength is based on the strength of the concrete which has been used (1.6) instead of adhesive resin, this yields a significant underestimation to the bond strength of the fastening. Thus, the estimated actual bond strength is based on the bond strength of the used adhesive resins in table 3: $\boldsymbol{\tau}_{\mathbf{a}}=25$ $\mathrm{N} / \mathrm{mm}^{2}$ (epoxy), $\tau_{\mathbf{a}}=19 \mathrm{~N} / \mathrm{mm}^{2}$ (urethane) and $\boldsymbol{\tau}_{\mathbf{a}}=20 \mathrm{~N} / \mathrm{mm}^{2}$ (In-organic) are used for the prediction. The values resulting from the bond failure $\left(T_{a 3}\right)$ equation in (1.5) are:

$\begin{array}{lll}\text { Steel failure } & \mathbf{T}_{\mathbf{a} 1}=137.7 \mathrm{kN} \\ \text { Concrete failure } & \mathbf{T}_{\mathbf{a} 2}=93.2 \mathrm{kN} \\ \text { Bond failure } & \mathbf{T}_{\mathbf{a} 3}=201.1 \mathrm{kN} \\ \text { Bond failure } & \mathbf{T}_{\mathbf{a} 3}=152.8 \mathrm{kN} \\ \text { Bond failure } & \mathbf{T}_{\mathbf{a} 3}=162.8 \mathrm{kN}\end{array}$

with $\tau_{\mathbf{a}}=25 \mathrm{~N} / \mathrm{mm}^{2}$ with $\boldsymbol{\tau}_{\mathbf{a}}=19 \mathrm{~N} / \mathrm{mm}^{2}$ with $\boldsymbol{\tau}_{\mathbf{a}}=20 \mathrm{~N} / \mathrm{mm}^{2}$
At higher temperatures (from $50^{\circ} \mathrm{C}$ ) the bond strength of adhesive resin which used for the equation (1.5) is based on the tests of [CSTB 2011] for the Hilti HIT-HY 200 A\&R (7). From this, the bond strength $\boldsymbol{\tau}_{\mathbf{a}}$ from $50^{\circ} \mathrm{C}$ to $200^{\circ} \mathrm{C}$ was withdrawn then calculate the bond failure (tensile load) at respectively temperatures. Although bond strength withdrawn from (7) is only for epoxy but it is used for the two other kinds as the reference. The results are in Table 4.

Determined by the tests: specimen is heated in the oven until the temperature in the adhesive which is measured by the two thermocouple reaches an average of the target temperature. After that, the tensile load is applied and slowly increased while the displacement is measured. The speed of acting tensile load is about $0.02 \mathrm{kN} / \mathrm{mm}^{2}$ per second based on a guideline in the standard test method of adhesive post-installed anchors in reference (10). At the indicative displacement of $30 \mathrm{~mm}$ it is considered failure and the load is noted. The measured temperatures are $50^{\circ} \mathrm{C}, 70^{\circ} \mathrm{C}, 80^{\circ} \mathrm{C}, 100^{\circ} \mathrm{C}, 130$ and $200^{\circ} \mathrm{C}$, with two specimens tested at each temperature. The heating condition is around $0.4^{\circ} \mathrm{C} / \mathrm{min}$, with the slowest at $0.32^{\circ} \mathrm{C} / \mathrm{min}$ and the fastest $0.5^{\circ} \mathrm{C} / \mathrm{min}$. Generally, the furnace is set to heat up to $400^{\circ} \mathrm{C}$. It has done with only epoxy adhesive type. The results were carried out in Table 5.

\section{2. 3. 2 Pattern II}

In the pattern II test: Use the results of the pattern I to make the tensile load to the specimens (the tensile load determined by prediction and experiment of Pattern I was applied) and heat up until failure mode occurred. At the indicative displacement of $30 \mathrm{~mm}$, it is considered failure, the failure temperature was noted The time of heating up to the failure temperature depending on the target temperature itself and the temperature at which the furnace is set. The heating speed and acting tensile load speed are the same as the pattern I.

\section{Result}

\section{1 Pattern I Test Results - Prediction}

The displacement and load parameter until bond failure occurs are given in Figure 4. The bond strength of adhesive resins have been predicted by [CSTB 2011] can be seen in the Table 4 .
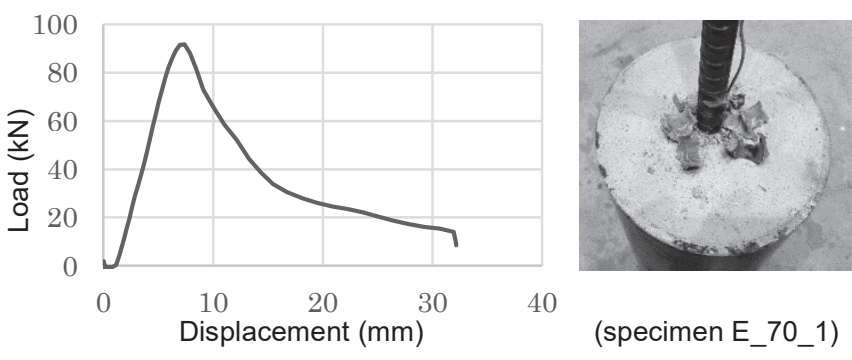

Fig.4 Displacement and Load until Bond failure 
Table 4 Predicted bond strength at high temperatures

\begin{tabular}{|c|c|c|}
\hline Temperature & $\begin{array}{c}\text { Bond Strength } \\
\text { Prediction }\end{array}$ & Tensile Load \\
\hline${ }^{\circ} \mathrm{C}$ & $\left(\mathrm{N} / \mathrm{mm}^{2}\right)$ & $(\mathrm{kN})$ \\
\hline 20 & $25 / 19 / 20^{*}$ & $201 / 158 / 162^{*}$ \\
\hline 50 & 14 & 112 \\
\hline 60 & 12 & 96 \\
\hline 70 & 10 & 80 \\
\hline 80 & 6 & 32 \\
\hline 100 & 4 & 24 \\
\hline 130 & 3 & 16 \\
\hline$\geq 200$ & 2 & 38 \\
\hline
\end{tabular}

*: Epoxy, Urethane, and In-organic respectively.

\section{2 Pattern I Test Results - Experiment tests}

Table 5 shows the bond strength of adhesive post-installed anchor has been measured by experiment for the Epoxy type.

Table 5 Measured bond strength for Epoxy type - Pattern I

\begin{tabular}{|l|c|c|c|}
\hline Specimen & $\begin{array}{c}\text { Temperature } \\
\left({ }^{\circ} \mathrm{C}\right)\end{array}$ & $\begin{array}{c}\text { Tensile Load } \\
\text { measured }(\mathrm{kN})\end{array}$ & $\begin{array}{c}\text { Failure } \\
\text { mode }\end{array}$ \\
\hline E_50_1 & 50 & 142.8 & B \\
\hline E_70_1 & 70 & 91.6 & B \\
\hline E_80_1 & 80 & 75.6 & B \\
\hline E_100_1 & 100 & 41.4 & B \\
\hline E_130_1 & 130 & 33 & B \\
\hline E_200_1 & 200 & 23.3 & B \\
\hline E_50_2 & 50 & 146.8 & B \\
\hline E_70_2 & 70 & 105.7 & B \\
\hline E_80_2 & 80 & 80.9 & B \\
\hline E_100_2 & 100 & 31.1 & B \\
\hline E_130_2 & 130 & 31.6 & B \\
\hline E_200_2 & 200 & 23.6 & \\
\hline
\end{tabular}

Note) (S): Steel failure (C): Concrete failure $\quad$ (B): Bond failure

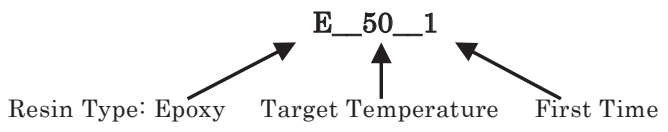

\section{3 Pattern II Test Results - based on Pattern I Prediction}

Table 6 and Figure 5 below are given the results of pattern II test for Epoxy resin type.
Table 6 Pattern II results for Epoxy type

\begin{tabular}{|c|c|c|c|c|}
\hline & $\begin{array}{c}5 \\
\text { Failure } \\
\text { Temp. } \\
\left({ }^{\circ} \mathrm{C}\right)\end{array}$ & $\begin{array}{c}\text { Tensile } \\
\text { Load } \\
(\mathrm{kN})\end{array}$ & $\begin{array}{c}\text { Bond Stress } \\
\left(\mathrm{N} / \mathrm{mm}^{2}\right)\end{array}$ & $\begin{array}{c}\text { Failure } \\
\text { mode }\end{array}$ \\
\hline E_50_1 & 55 & 112 & 14 & B \\
\hline E_70_1 & 59 & 80 & 10 & B \\
\hline E_60_1 & 65.6 & 96 & 12 & B \\
\hline E_80_1 & 89.7 & 48 & 6 & B \\
\hline E_100_1 & 100 & 32 & 4 & B \\
\hline E_130_1 & 123.5 & 24 & 3 & B \\
\hline E_200_2 & 290 & 20 & 2.5 & B \\
\hline E_200_1 & 301 & 16 & 2 & B \\
\hline
\end{tabular}

The data show that there is a significant deterioration of the strength of the adhesive when the temperature is elevated. At $60^{\circ} \mathrm{C}$ already the bond strength has dropped by about $60 \%$ to 10 $\mathrm{N} / \mathrm{mm}^{2}$ compared to $25^{\circ} \mathrm{C}$ (normal), going further down to $2 \mathrm{~N} / \mathrm{mm}^{2}$ by $200^{\circ} \mathrm{C}$. The loss in strength occurs very fast in the beginning and slows down when higher temperatures are reached.

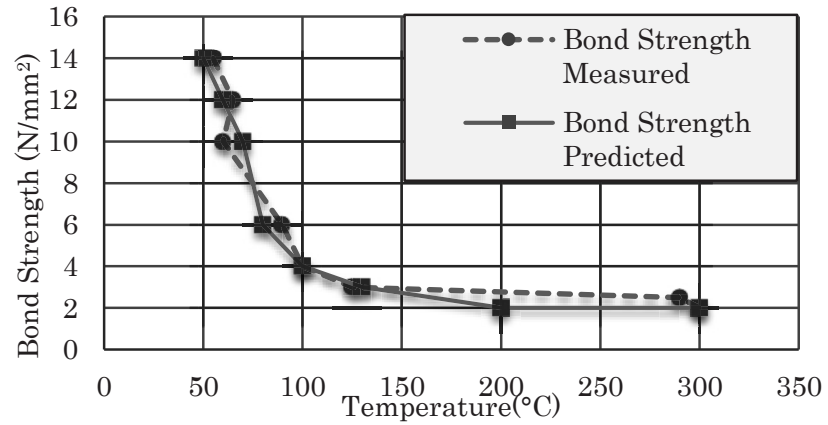

Fig.5 Bond strength result for Epoxy resin type

The same tendency for the losing bond strength in urethane resin when temperature elevated, but it has more stable when temperature under $100^{\circ} \mathrm{C}$. From $100^{\circ} \mathrm{C}$ to $130^{\circ} \mathrm{C}$, it declined rapidly and deteriorated slightly until the temperature reached $200^{\circ} \mathrm{C}$. The results of pattern II test for urethane resin as it is seen in Table 7 and Figure 6 below.

Table 7 Pattern II results for Urethane type

\begin{tabular}{|c|c|c|c|c|}
\hline \multicolumn{5}{|c|}{ Urethane (U) } \\
\hline Specimen & $\begin{array}{c}\text { Failure } \\
\text { Temperature } \\
\left({ }^{\circ} \mathrm{C}\right)\end{array}$ & $\begin{array}{c}\text { Tensile } \\
\text { Load } \\
(\mathrm{kN})\end{array}$ & $\begin{array}{c}\text { Bond } \\
\text { Stress } \\
\left(\mathrm{N} / \mathrm{mm}^{2}\right)\end{array}$ & $\begin{array}{c}\text { Failure } \\
\text { mode }\end{array}$ \\
\hline U_50_1 & 46 & 112 & 14 & B \\
\hline U_50_2 & 53 & 105 & 13 & B \\
\hline U_60_1 & 79.8 & 96 & 12 & B \\
\hline U_70_1 & 102 & 80 & 10 & B \\
\hline U_80_1 & 136 & 48 & 6 & B \\
\hline U_100_1 & 194 & 32 & 4 & B \\
\hline
\end{tabular}




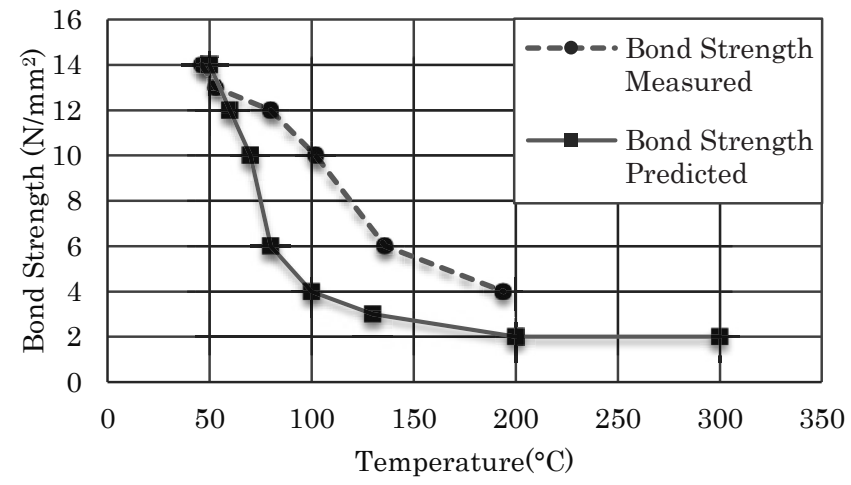

Fig.6 Bond strength result for Urethane type

For the In-organic resin type, the results of pattern II test as it is seen in Table 8 and Figure 7 below.

Table 8 Pattern II results for In-organic type

\begin{tabular}{|c|c|c|c|c|}
\hline \multicolumn{5}{|c|}{ In-Organic (0) } \\
\hline Specimen & $\begin{array}{c}\text { Failure } \\
\text { Temp. } \\
\left({ }^{\circ} \mathrm{C}\right)\end{array}$ & $\begin{array}{c}\text { Tensile } \\
\text { Load } \\
(\mathrm{kN})\end{array}$ & $\begin{array}{c}\text { Bond } \\
\text { Stress } \\
\left(\mathrm{N} / \mathrm{mm}^{2}\right)\end{array}$ & $\begin{array}{c}\text { Failure } \\
\text { mode }\end{array}$ \\
\hline O_50_1 & 82 & 112 & 14 & B \\
\hline O_50_2 & 60.7 & 105 & 13 & B \\
\hline O_60_1 & 53.1 & 96 & 12 & B \\
\hline O_60_2 & 102 & 88.5 & 11 & B \\
\hline O_130_1 & 106 & 72 & 9 & B \\
\hline O_130_2 & 109 & 64 & 8 & B \\
\hline O_200_1 & 116 & 60.3 & 7.5 & B \\
\hline O_200_2 & 275 & 56.3 & 7 & B \\
\hline
\end{tabular}

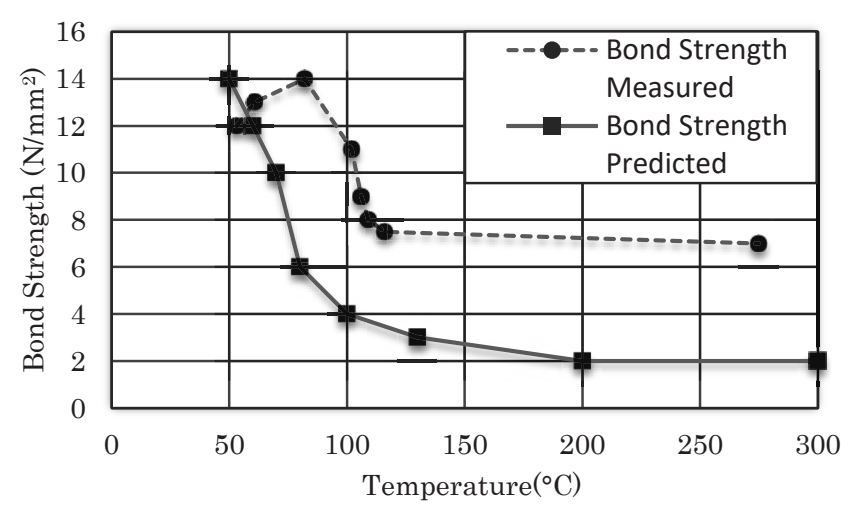

Fig.7 Bond strength result for In-organic type

In this test, the tensile load has been applied from $112 \mathrm{kN}$ (14 $\left.\mathrm{N} / \mathrm{mm}^{2}\right)$ to $56.3 \mathrm{kN}\left(7 \mathrm{~N} / \mathrm{mm}^{2}\right)$ to investigate the bond strength when the temperature rose. Figure 7 shows that it fluctuated and very unpredictable. The results compared to prediction are very different.
Generally, it could be seen that Epoxy has the lower capability to stay when temperature rises than the two others resin. In epoxy resin type, the bond strength decreased rapidly from the beginning then gradually deteriorated while in urethane and inorganic type, it has fluctuated in a wide range compared with prediction data.

\section{4 Pattern II Test Results - based on Pattern I Experiments} Table 9 below shows the results of pattern II test for Epoxy type. The tensile load is based on the result of experiments in pattern I, the failure temperature is determined when the specimen is considered as bond failure occurred. The relationship of failure bond strength and temperature for epoxy resin are given in Figure 8 .

Table 9 Pattern II Results for Epoxy type

\begin{tabular}{|c|c|c|c|}
\hline Specimen & $\begin{array}{c}\text { Failure } \\
\text { Temp. } \\
\left({ }^{\circ} \mathrm{C}\right)\end{array}$ & $\begin{array}{c}\text { Tensile Load } \\
(\mathrm{kN})\end{array}$ & Failure mode \\
\hline E_50_1 & 48.8 & 142.8 & B \\
\hline E_70_1 & 60.5 & 91.6 & B \\
\hline E_80_1 & 68.3 & 75.6 & B \\
\hline E_100_1 & 97.3 & 41.4 & B \\
\hline E_130_1 & 130.3 & 33 & B \\
\hline E_200_1 & 275.5 & 23.3 & B \\
\hline E_50_2 & 52.4 & 146.8 & B \\
\hline E_70_2 & 62.3 & 105.7 & B \\
\hline E_80_2 & 65.4 & 80.9 & B \\
\hline E_100_2 & 84 & 31.1 & B \\
\hline E_130_2 & 87.7 & 31.6 & B \\
\hline E_200_2 & 180.3 & 23.6 & B \\
\hline
\end{tabular}

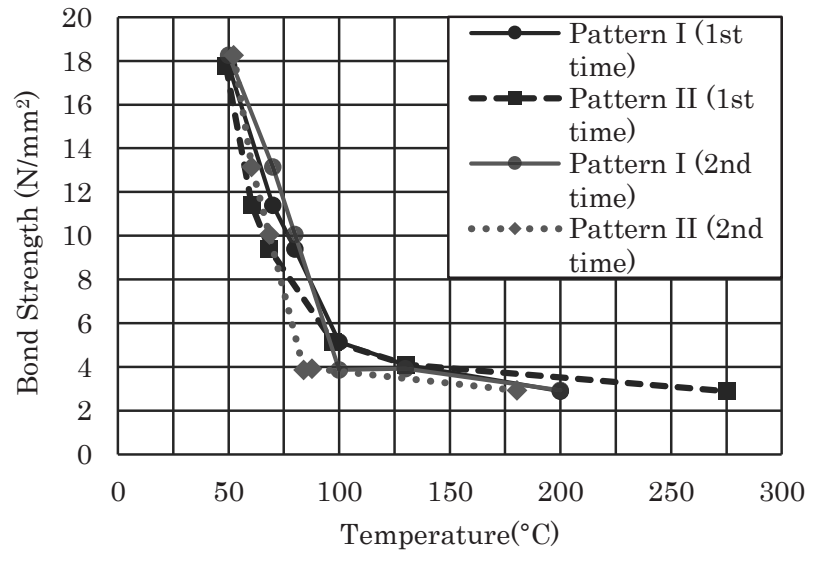

Fig.8 The relationship of failure bond strength and temperature

The losing bond strength in two patterns test is in the same tendency but it could be seen that when the temperature is under $100^{\circ} \mathrm{C}$, there is no significant difference. When applied the same 
constant load, from $50^{\circ} \mathrm{C}$ to $100^{\circ} \mathrm{C}$ during the fire, the temperatures that bond failure mode occurred of two patterns are not changed much. Thus, it is supposed that the pattern I loading test can be used as a method for predicting the bond strength of epoxy injection type of pattern II test in this range of temperature while from above $100^{\circ} \mathrm{C}$, there is a need to do more tests to determine if the losing bond strength can be predicted.

Figure 9 shows the bond failure and temperature relationship between two kinds of pattern II test for epoxy (based on prediction and experiment of the pattern I).

It clearly showed the same trend of two testing methods. The bond strength reduced considerably at high temperature from the beginning then gradually deteriorated. There is a need to do more tests with a smaller pace of temperature to figure out the connection between two methods.

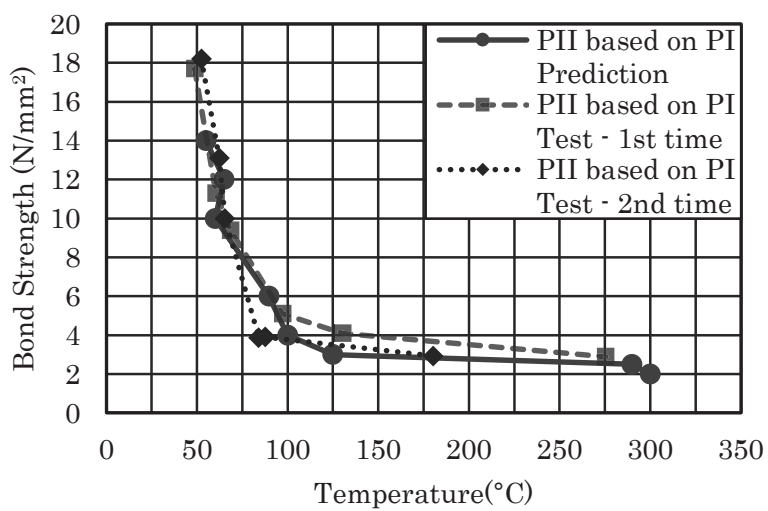

Fig.9 The relationship of failure bond strength and temperature between two kinds of pattern II tests

\section{Conclusion}

Epoxy injection type decreased to about $1 / 10$ in about $280{ }^{\circ} \mathrm{C}$ compared to average temperature. Urethane injection type decreased to about $1 / 5$ in about $200{ }^{\circ} \mathrm{C}$. Also, in In-organic injection type reduced about $1 / 3$ in about $270{ }^{\circ} \mathrm{C}$ compared to normal.

For the testing method, the pattern I test is simple to experiment because, in the pattern II, the load gradually lost by the time when temperature elevated, and it was added manually every time it lost to keep the load stable. Thus, the pattern II test is more complicated and closer to the real situation.

The pattern I test (by experiment) can be used as a method for predicting the bond strength of epoxy injection type of pattern II test for under $100^{\circ} \mathrm{C}$.

\section{Future Prospect}

To clarify the relations between pattern I and pattern II test, it needs to do more test with the little pace of temperature. When the relations are carried out, it brings the practical advantages to predict the bond strength by the simple method.
After this, the study field can become to "after fire" study field. In this field, the after fire tests should also be carried out to find the point that at which temperatures the bond strength starts to deteriorate and how it deteriorated compare to during the fire condition. From the results of after fire test, the relationships with during fire tests can be carried out, thus can predict the bond strength of the anchor system at higher temperatures.

Furthermore, there are eventually full-scale tests with anchors in actual concrete members to investigate a situation very close to the application in reality. When designers assume the temperature and tensile load of adhesive post-installed rebar of fire resistance in fire structural design of renewal applications they can design what temperature need to target and what tensile load in long terms need to choose base on the results of the experiments soon.

\section{References}

1) Werner Fuchs and John Silva.: EOTA APPROACH TO QUALIFICATION AND DESIGN OF POST-INSTALLED ADHESIVE ANCHORS FOR FIRE EXPOSURE, ACI SP-283, 2012

2) Rolf Eligenhausen, John F. Silva.: Behaviour of anchors in fire, Anchorage in Concrete Construction, Ernst \& Sohn, A Wiley Company, 2006

3) Andra Hoermann-Gast and Jacob Olsen.: The Effects of Temperature on Post-installed Adhesive Anchors, International Code Council (ICC), 2014

http://concreteanchors.org/publications/ac308_temperature.pdf 4) Xin Wang, ChangJiu Jiang, KaoZhong Zhao, Xiang Rui Chen.: Experimental Study on Fire Resistance Properties of Post-Installed Rebar Connection, Advanced Materials Research, ISSN: 1662-8985 Vols. 671-674, 1877-1882 2013

5) Omori Masanori.: Evaluation of Fire Resistance Performance of Post-installed Adhesive Anchors, Summaries of Technical Papers of Annual meeting, Architectural Institute of Japan, C-2, pp. 745-746, 1995

大森正秀他：樹脂系あと施エアンカーの耐火性能評価，日本建築学会大会 学術講演梗概集, C-2, pp. 745-746, 1995

6) SONG Changsuk, OWA Seira, LE TIEN THUAN, IKEDA Kenichi.: Experimental Study on Bond Strength of Adhesive Injection Post-installed Rebar During High Temperature Assumed as Reinforced Concrete Connections in Long Term. Part 1, Summaries of Technical Papers of Annual Meeting, Architectural Institute of Japan 7) SONG Changsuk, OWA Seira, LE TIEN THUAN, IKEDA Kenichi.: Experimental Study on Bond Strength of Adhesive Injection Post-installed Rebar During High Temperature Assumed as Reinforced Concrete Connections in Long Term. Part 2, Summaries of Technical Papers of Annual Meeting, Architectural Institute of Japan

8) Technical report No.26033756-HIT-HY 200-A\&R.: HILTI HIT-HY 200-A and HILTI HIT-HY 200-R injection systems in conjunction with concrete reinforcing bar ( $\varphi 8$ to $32 \mathrm{~mm}$ ) and subjected to fire exposure, CSTB/EOTA, 2014

9) The Japan Building Disaster Prevention Association (2005).: Standard for Seismic Evaluation of Existing Reinforced Concrete Buildings, 2001, Guidelines for seismic retrofit of existing reinforced concrete buildings, 2001, and technical manual for seismic evaluation and seismic retrofit of existing reinforced concrete buildings, 2001. First English edition, Translated by Building Research Institute, pp.2-50

10) AIJ.: Design Recommendations for Composite Constructions, pp.252-269, 274-308, 2010.

11) Japan Construction Anchor Association (JCAA).: Text of Technical Course of post-installed anchors, 2015 


\section{和文要約}

本論文は, エポキシ系樹脂, ウレタン系樹脂, 無機系注入方式接 着系あと施工アンカーの火災時の付着破壊モードにおける引張付着 強度に関する実験的研究である。

ファスニングとしてのあと施工アンカーは日本では一般的に既存 建造物の耐震補強等で使用されているが，火災時における荷重支持 能力についてはあまり注目されてない。ヨーロッパでは既に検証さ れているが，3 つの樹脂 (エポキシ系、ウレタン系、無機系)の注入 方式接着系あと施エアンカー(カートリッジ型) と鉄筋に関する高温 下に暴露された際の挙動の実験的検証が本研究の主旨である。

実験は 2 つのパターンで行った。第一パターンでは最大引張荷重 の計測を行った。第一パターンの実験方法としては目標温度まで試 験体の内部温度を上昇させた後, 付着破壊が生じるまで引張荷重を 載荷し, 最大引張荷重を測定した。第二のパターンも火災時の検証 であるが，第一パターンで得られた付着破壊時の最大引張荷重を載 荷した状態で, 試験体温度を上昇させながら付着破壊が生じる時点 の温度を測定する方法にした。特に, 第二パターンは, 荷重が載荷 された状況下での高温暴露であるため, 実際の火災時の状況を再現 したモデルである。全ての試験体の仕様は，コンクリートを充填し た鋼管（直径 $\Phi 150$, 高さ $300 \mathrm{~mm}$ ) に接着系アンカー $(S D 685, D 16 \times$ 160 (10Da), 穿孔径 $20 \mathrm{~mm}$ ) を打設した。試験を行った温度は $50^{\circ} \mathrm{C}$, $70^{\circ} \mathrm{C}, 80^{\circ} \mathrm{C}, 100^{\circ} \mathrm{C}, 130^{\circ} \mathrm{C}, 200^{\circ} \mathrm{C}$, 計 46 体試験体を用いた, 以下 にその結果をまとめる。
○高温時の付着強度は, 接着系アンカーの主剤の種類によって, 異なる傾向を示す。

○エポキシ系樹脂は, 常温時と比較して約 $280^{\circ} \mathrm{C}$ の時点で付着強 度が約 $1 / 10$ に減少した。ウレタン系樹脂タイプは約 $200^{\circ} \mathrm{C} の$ 時点で付着強度は常温時の約 $1 / 5$ に減少した。無機系タイプ では、常温時と比較して約 $270^{\circ} \mathrm{C}$ の時点で付着強度が約 $1 / 3$ に 減少した。

○実験方法については、第一パターンによる実験方法が簡便で あり、第二パターンの方が複雑ではあるが実際の火災時の状 況に近い。

○ 第一パターンは, $100^{\circ} \mathrm{C}$ 未満のエポキシ系樹脂タイプの接着系 アンカーの火災時の付着強度試験として, 第二パターンの試 験方法を簡易試験として用いることが出来る。

第一パターンと第二パターンの関係を明確にするために，より小 さな温度ステップでより多くの実験データを蓄積する必要があり。 その関係性を明らかにすることができれば，より簡便な試験方法で 火災時の付着強度を予測できる。今後の課題としてどのあたりの温 度で付着強度が低下し始め, 炭化が促進されるかを, 火災時と比較し て調べるために, 火災後の実験を実施する必要がある。火災後の結 果から, 火災時の結果との関係を確認・検証することが出来れば, 高温時の接着系あと施工アンカーの付着耐力を計算し解析すること で，火災時の付着強度を予測することができると考えられる。最終 的には，実大の接着系あと施工アンカーを用いた火災時の挙動の実 験的検証を行う予定である。 